STANOVLENIE ROSSIISKOGO SAMODERZHAVSTVA: ISSLEDOVANIE SOTSIAL'NO-POLITICHESKOI ISTORII VREMENI IVANA GROZNOGO. By S. O. Shmidt. Moscow: "Mysl'," 1973. 359 pp. 1.43 rubles.

Shmidt's title promises more than his three specialized and unconnected studies and perfunctory foreword and afterword deliver. Also, only two studies-on the Moscow rising of June 1547, pompously called "The Beginning of the Moscow Tsardom," and on "The Making of Councils of the Land"-are confined to Ivan Groznyi. The third, "Mestnichestvo and Absolutism (a Formulation of the Problem)," spans early modern Russia, late fifteenth to late eighteenth century. Specialists will recognize Shmidt's essays from his published articles (listed p. 313, n. 19). The second and third follow earlier articles word for word save for additional footnotes, minor editorial changes, and expanded arguments to meet past criticism.

Read for the first time, Shmidt's studies are rewarding. He sketches the history of mestnichestvo as a dynamic relationship between the ruler's developing raison d'état in demanding service and the aristocracy's claim to hereditary rights. His argument, too involved to trace here, is original and the best recent account for specialist or nonspecialist. In the other essays Shmidt leads us adroitly and in detail through the sources, and sticks close to them in the analysis of events. He grossly exaggerates the significance of the rising of 1547 (p. 14, "the most important event of the political history of Russia in the sixteenth century"), but irrefutably establishes that the Moscow fire triggered a massive "primitive" rebellion of townspeople which shocked Ivan Groznyi into beginning to consolidate state power. Shmidt's essay on Councils of the Land is controversial. He claims to detect at least six expanded Councils of Boyar Duma, clergy, and others between 1547 and the first generally accepted Council of 1566 . To Shmidt they were Councils of the Land in-the-making. Other Soviet scholars claim that only some or none of these were genuine. Arguments turn either on differences about treacherously ambiguous evidence or on whether one accepts Lenin's assertion that Russia became a "classrepresentative monarchy" only in the seventeenth century. All protagonists admit that in assemblies from 1547 to $1564-65$ Ivan picked delegates, to a limited degree even for the Boyar Duma and the clergy. The remaining delegates were soldiers or bureaucrats. Shmidt occasionally accepts questionable sources that support his theories, such as the testimony of the late seventeenth-century Khrushchovshaia stepennaia kniga about a council in 1549. More important, he shows that Groznyi began what became a tradition, the packing of meetings of the Boyar Duma with other interested parties to force acceptance of the burdens of state-building. These assemblies were instruments to establish autocracy; and that of 1564-65, Shmidt ingeniously argues, included for the first time representatives of the town of Moscow and was a confrontation leading to the Oprichnina.

David B. Miller

Roosevelt University

BORIS GODUNOV: THE TRAGIC TSAR. By Ian Grey. New York: Charles Scribner's Sons, 1973. 188 pp. $\$ 8.95$.

Readers of Russian history who are already familiar with Ian Grey's biographies of Peter I, Ivan III, Ivan IV, and Catherine II will find his latest effort similar in approach and manner. In this volume Grey chronicles the narrative history of the 
life of Boris Godunov, drawing heavily from the classic accounts by Karamzin, Soloviev, and Platonov and the more recent scholarship of Zimin and Vernadsky. For those who know little of this period of history, his work can serve as a useful introduction.

Grey states that his intention was "to scrape away the accumulated calumnies of Boris Godunov and to portray him as an able and also an honest and even humane ruler." He then attempts to clear Godunov of implication in the death of Tsarevich Dnitrii by arguing the lack of evidence for such a charge. Yet he can adduce no new data for a rehearing of Godunov's case. Instead he marshals extensive examples of Godunov's humaneness and consideration as a ruler, hoping to clear his name by demonstrating that an act of murder was beyond his capability. Thus Grey's arguments rest upon data as tenuous as that often employed by Godunov's detractors. The serious reader will be better served by the impressive study of Godunov's reign by S. F. Platonov, recently reissued in English translation by Academic International Press.

Although Grey is careful to avoid factual errors, he employs an archaic system of transliteration for Russian names (e.g., Otrepyev) that will annoy those who feel that standardization in this realm has already been achieved. The author also reproduces Polish names in their Russian form (Mnishek, Krakov), instead of following the more rational custom of retaining their native spelling. The bibliography is sparse and dated.

JoSEPH L. WIECZYNSKI

Virginia Polytechnic Institute and State University

\section{THE SYSTEMATIZATION OF RUSSIAN GOVERNMENT: SOCIAL EVO- LUTION IN THE DOMESTIC ADMINISTRATION OF IMPERIAL RUSSIA, 1711-1905. By George L. Yaney. Urbana, Chicago, London: Uni- versity of Illinois Press, 1973. xvi, 430 pp. $\$ 13.50$.}

Mr. Yaney sets himself the formidable task of studying the "historical evolution through which the servitors gradually came to organize themselves to some extent around their common pretense and/or aspiration to operate within a formal legaladministrative system-the process by which the servitors came to depend on one another to act and think as if they believed that their laws and authorities had to be in logical order in order to possess legitimacy" (p. 5). The conceptual vagueness (and stylistic clumsiness) of this formulation compounds the difficulties of the reader, nor does Yaney's adherence to an outdated and simple-minded nominalist positivism help things. The author has obvious difficulty in dealing with abstract concepts; for example, the Senate is an institution, a legal symbol, an abstraction, a political system, a social group, and a set of rules at one point or another in the book. At another point (pp. 124-25) Yaney equates equity and system, and confuses digest and code (p. 263).

Put in less pretentious words than his own, Yaney's thesis is simple and quite suggestive: Since Peter I tried to undertake the modern transformation of Russian administration, and until 1905 (the logic of the cut-off date is not spelled out), the imperial government, both local and central, experienced three fundamental patterns of organization. The first one was senatorial (1701-1801), which according to Yaney continued the pre-Petrine function of exacting tribute and conscripting servitors, and merely aimed at discovering the law operative in society and ordering 